\title{
Teaching NeuroImages: Spinal cord infarct due to fibrocartilaginous embolism in an adolescent
}

Fábio A. Nascimento, MD, Wilfreda Lindsey, MD, Jill V. Hunter, MD, and Sarah Risen, MD

Neurology ${ }^{\circledR}$ 2020;94:e2495-e2496. doi:10.1212/WNL.0000000000009600

Figure Spine imaging
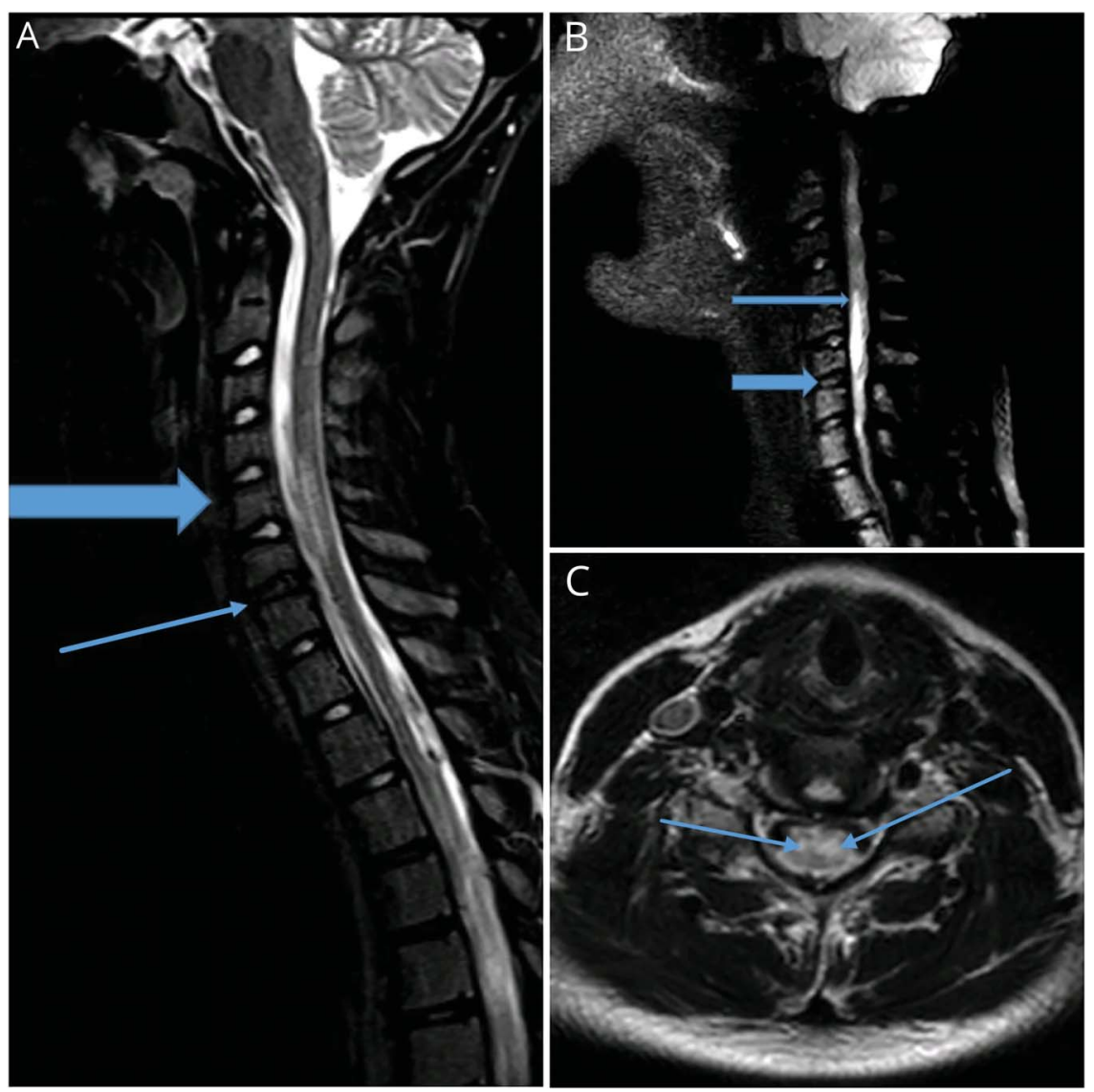

Sagittal T2 imaging (A) of the cervical spine demonstrates degenerative changes at the C6-7 disk interspace (thin arrow) and T2 hyperintensity is identified in the ventral cervical cord opposite to C5 and C6 (thick arrow). Sagittal diffusion-weighted imaging (B) reveals restricted diffusion abnormality in the ventral cervical cord extending from the C4-5 level (thin arrow) down to the C6-7 level (thick arrow). Axial T2 imaging (C) at the level of the C5-6 disk space shows $\mathrm{T} 2$ hyperintensity in the anterior, left greater than right, cervical cord (thin arrows).

A 15-year-old healthy, active girl presented with acute bilateral upper extremity tingling and hand weakness while playing golf; within several hours, she developed numbness and weakness in all limbs. She denied preceding trauma and bowel/bladder incontinence. Examination showed global weakness, normal tone and reflexes, a C5 sensory level, and decreased light touch/temperature/pinprick in all limbs. Neuroimaging revealed an anterior spinal artery cervical cord infarct (figure), along with a degenerative disk, attributed to fibrocartilaginous embolism.

\section{Correspondence}

Dr. Nascimento

nascimento.fabio.a@gmail.com
MORE ONLINE

\section{$\rightarrow$ Teaching slides}

links.lww.com/WNL/

B94

From the Department of Neurology (F.A.N.), Division of Neurology and Developmental Neuroscience, Department of Pediatrics (W.L., S.R.), and Department of Radiology (J.V.H.), Baylor College of Medicine, Houston, TX.

Go to Neurology.org/N for full disclosures. Funding information and disclosures deemed relevant by the authors, if any, are provided at the end of the article. 
Despite being a rare cause of spinal cord infarct, adult and pediatric neurologists should include fibrocartilaginous embolism as a possible etiology in patients with ischemic myelopathy. ${ }^{1,2}$

\section{Study funding}

No targeted funding reported.

\section{Disclosure}

F.A. Nascimento is a member of the Neurology ${ }^{\circledR}$ Resident \& Fellow Section Editorial Team. W. Lindsey, J.V. Hunter, and S. Risen report no relevant disclosures. Go to Neurology.org/ $\mathrm{N}$ for full disclosures.

Appendix Authors

\begin{tabular}{|c|c|c|}
\hline Name & Location & Contribution \\
\hline $\begin{array}{l}\text { Fábio A. } \\
\text { Nascimento, } \\
\text { MD }\end{array}$ & $\begin{array}{l}\text { Baylor College of } \\
\text { Medicine, } \\
\text { Houston, TX }\end{array}$ & $\begin{array}{l}\text { Designed and conceptualized } \\
\text { study, analyzed and interpreted } \\
\text { the data, drafted the manuscript }\end{array}$ \\
\hline
\end{tabular}

Appendix (continued)

\begin{tabular}{lll}
\hline Name & Location & Contribution \\
\hline $\begin{array}{l}\text { Wilfreda } \\
\text { Lindsey, MD }\end{array}$ & $\begin{array}{l}\text { Baylor College of } \\
\text { Medicine, } \\
\text { Houston, TX }\end{array}$ & $\begin{array}{l}\text { Analyzed and interpreted the } \\
\text { data, drafted the manuscript }\end{array}$ \\
\hline $\begin{array}{l}\text { Jill V. Hunter, } \\
\text { MD }\end{array}$ & $\begin{array}{l}\text { Baylor College of } \\
\text { Medicine, } \\
\text { Houston, TX }\end{array}$ & $\begin{array}{l}\text { Analyzed and interpreted the } \\
\text { data, revised the manuscript }\end{array}$ \\
$\begin{array}{l}\text { Sarah Risen, } \\
\text { MD }\end{array}$ & $\begin{array}{l}\text { Baylor College of } \\
\text { Medicine, } \\
\text { Houston, TX }\end{array}$ & $\begin{array}{l}\text { Designed and conceptualized } \\
\text { study, analyzed and interpreted } \\
\text { the data, revised the manuscript, } \\
\text { supervised the study, final } \\
\text { approval }\end{array}$ \\
& & \\
\hline
\end{tabular}

\section{References}

1. Yamaguchi H, Nagase H, Nishiyama M, et al. Fibrocartilaginous embolism of the spinal cord in children: a case report and review of literature. Pediatr Neurol 2019; 99:3-6.

2. AbdelRazek MA, Mowla A, Farooq S, et al. Fibrocartilaginous embolism: a comprehensive review of an under-studied cause of spinal cord infarction and proposed diagnostic criteria. J Spinal Cord Med 2016;39:146-154. 


\section{Neurology}

\section{Teaching NeuroImages: Spinal cord infarct due to fibrocartilaginous embolism in an adolescent}

Fábio A. Nascimento, Wilfreda Lindsey, Jill V. Hunter, et al.

Neurology 2020;94;e2495-e2496 Published Online before print May 7, 2020

DOI 10.1212/WNL.0000000000009600

This information is current as of May 7, 2020

\section{Updated Information \& Services}

References

Subspecialty Collections

Permissions \& Licensing

Reprints including high resolution figures, can be found at: http://n.neurology.org/content/94/23/e2495.full

This article cites 2 articles, 0 of which you can access for free at: http://n.neurology.org/content/94/23/e2495.full\#ref-list-1

This article, along with others on similar topics, appears in the following collection(s):

\section{All Cerebrovascular disease/Stroke}

http://n.neurology.org/cgi/collection/all_cerebrovascular_disease_strok e

\section{Embolism}

http://n.neurology.org/cgi/collection/embolism

Infarction

http://n.neurology.org/cgi/collection/infarction

Spinal cord infarction

http://n.neurology.org/cgi/collection/spinal_cord_infarction Stroke in young adults

http://n.neurology.org/cgi/collection/stroke_in_young_adults

Information about reproducing this article in parts (figures,tables) or in its entirety can be found online at:

http://www.neurology.org/about/about_the_journal\#permissions

Information about ordering reprints can be found online:

http://n.neurology.org/subscribers/advertise

Neurology ${ }^{\circledR}$ is the official journal of the American Academy of Neurology. Published continuously since 1951, it is now a weekly with 48 issues per year. Copyright @ 2020 American Academy of Neurology. All rights reserved. Print ISSN: 0028-3878. Online ISSN: 1526-632X.

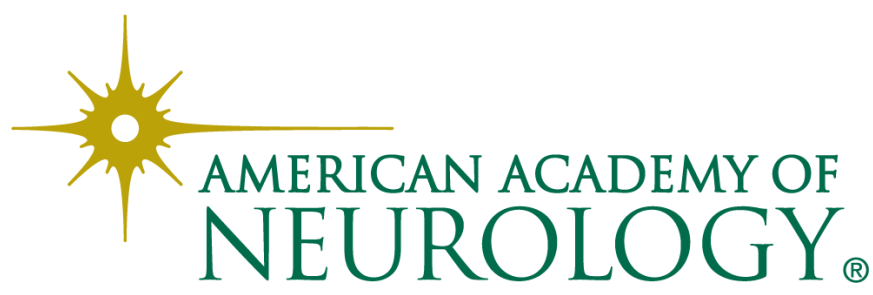

